\title{
15. HIV and Security in Papua New Guinea: National and Human Insecurity ${ }^{1}$
}

\author{
MICHAEL O'KEEFE
}

\section{Introduction}

Much of the discussion in this volume focuses, understandably, on particular experiences and responses to HIV and AIDS in PNG, just as much of the international discourse focuses on the immediate needs of prevention, treatment and care. Yet the impact of the epidemic is potentially felt across all of society, and an unchecked epidemic will further challenge the collective viability of Papua New Guinea.

Such a broad analysis might be expected in the field of International Relations, attempts to provide this overview of the epidemic have been made (e.g., Altman 2003; Brower and Chalk 2003; Eberstadt 2002; Barnett and Whiteside 2002). Most mainstream International Relations research, however, concentrates on threats to states - particularly military threats - and the implications of a full-scale HIV epidemic are not developed in their calculations, although for political reasons the epidemic may rate a cursory mention. There are, of course, exceptions: indeed US intelligence agencies were among the first to begin this broad sort of analysis (CIA 2000).

This chapter reflects on larger strategic questions about the overall impactsocial, political, economic and cultural - of the epidemic on an already fragile state where national cohesion is very weak, and society is mainly organised at kin and local levels. Studies of the strategic effects of HIV (particularly on its possible economic impact (e.g. CIE 2002, HEMIS 2006)) have not linked this to more general research on the development in PNG and various factors that threaten political and social stability. The following discussion is framed by the concept of human security and the application of this framework to the epidemic in PNG. At the same time an 'apocalyptic' view of HIV and security

1 Thanks to Dennis Altman and the editor for comments on this chapter. Of course, any errors are my own. 
will be avoided. As evidence from sub-Saharan Africa suggests, the worst affected societies are remarkably resilient even when infection rates reach 30-40 percent of the young adult population (e.g. de Waal 2005, 119).

Notwithstanding problems of surveillance and reporting (PNG National AIDS Council 2008, 75-77), the epidemic clearly has become entrenched in PNG and has the potential to become significantly worse. Ben Reilly has written of the potential for the 'Africanisation of the Pacific' (Reilly 2000), and if this prediction is accurate then HIV and AIDS will be a central part of this process. However, much of the 'African experience' may not be relevant to PNG and many objections to the 'Africanisation' thesis have been raised (e.g. Fraenkel 2004a; Chappell 2005) and these objections may similarly apply to HIV (O'Keefe 2008; Hammar 2007; Hammar this volume). For instance, PNG is at a much earlier stage in the epidemic than the countries of southern Africa and local factors always affect the epidemic's course. Therefore, in the following discussion the relevance of the 'African experience' will be treated with caution.

Regardless of these qualifying statements, the following overview highlights the major challenges that PNG society and the state are facing, with an emphasis on what can be learned from the broader international experience. This chapter does not seek to make all the connections with the situation on the ground in PNG but rather, to make some key connections and to provide a frame that PNG specialists can use to judge for themselves the relevance of various aspects of the international experience.

\section{The Meaning of Security}

Various types of insecurity are often conflated, which causes some confusion, especially when it is unclear whether the discussion refers to the security of the most affected states, societies or people, or to the wider international system. In very simplistic terms one might posit a tension between a narrow, state- and military-centred vision of security, and one that places an emphasis on human welfare and survival. The Cold War policy of 'Mutually Assured Destruction' (MAD), which would sacrifice all human life to 'defeat' an enemy, is symbolic of a view of security that is totally centred on the state.

Mainstream International Relations theorists regard the state as the primary unit of analysis. Statehood involves the possession and maintenance of formal sovereignty, which has internal and external dimensions. Theoretically, a state must acknowledge the legitimacy of international law, and is recognised by the international community of states as the legitimate authority over a designated geographic area. 
Territory must be held, borders must be protected against encroachments by other states, and authority must be maintained within these borders. That is, a state's 'monopoly of violence' must be maintained. These aspects of formal sovereignty explain why military security forms the basis of much debate in international relations and why most non-military issues are excluded from analysis.

In the contemporary world there are many 'states' whose control over their territory is in fact limited. For instance, state sovereignty in PNG has been challenged by the secessionist movement in Bougainville, the 'porous' borders with West Papua and the Solomon Islands and, in some areas, by the breakdown in law and order - but not by epidemic disease. Shocking as HIV statistics may be, few International Relations scholars see AIDS as a direct threat to states and, more specifically, to PNG as a state.

The primary source of orthodox state-centric threats is invasion and internal conflict (civil war), the former possibly removing the existing state altogether, the latter creating instability that could lead to state fragility. Internal conflict could be sponsored by another state or be caused by domestic rebellion. The likelihood of these types of threats developing in PNG is as follows:

\section{Cross-border Threats}

Strategic forecasts paint a benign picture: there are no external military threats to PNG likely for the foreseeable future (Australia 2005). If there were to be any such threat, then it would be more likely to be over the land border with West Papua. There is a paucity of commentary on this diplomatically sensitive topic but all indications are that an invasion by Indonesia is extremely unlikely. Cross-border incursions are more likely but would not threaten the PNG state (they would however erode its legitimacy).

\section{The Threat of Civil War and/or Rebellion}

Due to signs of internal instability in other South Pacific states, the threat of coup or rebellion might appear the most likely state-centric threat to security in PNG (May 2004). Several movements of a micronationalist character preceded and followed Independence in 1975, and over the last 30 years challenges to the PNG state have been launched from within. The Bougainville conflict and Sandline Affair are two of the most noteworthy, though tensions have also arisen from attempts to reform the PNG defence force (see Pantumari and Bamne this volume). However, so far these have not amounted to serious threats of a military coup. The key issue is that governments have changed in PNG in a relatively orderly fashion and national institutions have proved surprisingly 
resilient (if limited in capacity). Besides, the PNG military is small and multiethnic, and in recent years has been reduced in size (see Pantumari and Bamne, this volume).

\section{HIV as an Unorthodox State-centric Threat to PNG}

In fragile states such as PNG non-military sources of insecurity, such as natural disasters, transnational crime, and major epidemics can have a real impact on the ability of the state to function. For most people HIV and AIDS pose a greater threat than an orthodox military one, but analysing this requires a comprehensive 'threat matrix' that includes individual, societal and national/ state security. A similar debate has occurred over global warming. Critics of remedial actions to counter global warming, such as signing the Kyoto Protocol, are fighting a similar rearguard action against the orthodox military perspective of security. An extended treatment of human security would be out of place here although a valuable discussion of this concept can be found in Tow et al. (2000; see also Reid this volume).

It has been posited that HIV may prove a threat to the survival of the state in a number of ways. The most obvious is if increasing HIV rates lead to civil conflict. A causal link has been postulated between conflict and increased transmission of HIV in Sub-Saharan Africa, for example in Rwanda and the Congo, although there is also evidence that some conflicts may actually slow HIV transmission (Whiteside et al. 2006). (However, as noted earlier, PNG is unlikely to face the sort of intense levels of armed conflict that has plagued some African states.) The unlikely prospect of invasion or rebellion in PNG effectively removes the most credible link between HIV and state-centric threats.

More serious is the possible impact of HIV on domestic forces of law and order. It is often asserted that HIV prevalence in the military in some African states is disproportionately high (as in Angola and the Congo), especially during early stages of the epidemic, thus making the military a source of instability (Kendino 2005a; 2005b; Elbe 2003, esp. chapter 2). This instability could result from either rebellion or because the military is so weakened it can no longer defend the state. More recent research, however, has qualified the assertion that military populations tend to experience higher HIV prevalence than their civilian counterparts (Barnett and Prins 2005; Whiteside et al. 2006) and available prevalence figures suggest that the military in PNG has infection rates 
comparable to those of the general populace. ${ }^{2}$ Many observers actually see the Papua New Guinea Defence Force (PNGDF) as a source of stability, rather than a threat to the state. This puts paid to threat perceptions focused on increasing prevalence in the military as a source of instability but does not represent the end of the story. The PNGDF does take responsibility for its members and the rising costs of treatment and funeral expenses will impose a burden on its already tight budget (see Pantumari and Bamne this volume).

Of more concern is the effect of HIV and AIDS on the Royal Papua New Guinea Constabulary (RPNGC). The police have not been able to maintain law and order, or halt the declining law and order situation. Indeed, as several chapters indicate, many observers see the RPNGC as too often actively implicated in the escalation of law and order problems, including in sexual assaults (e.g. Luker and Dinnen this volume; Jenkins this volume; McLeod and Macintyre this volume). While there is little evidence suggesting that HIV is among the factors currently impacting on police efficiency, increased infection rates will presumably weaken the effectiveness of the force over time. As with the PNGDF, the diversion of resources to cover medical expenses will also have an impact on the RPNGC.

Higher HIV rates can increase and compound instability by limiting the ability of the law and order agencies to do their jobs. Assuming that criminal groups, refugees, illegal immigrants, and even neighbouring states might take advantage of any military and police ineffectiveness, even in the narrow terms of statecentric security, HIV becomes a concern. However, this assumes that these challengers to the state are not afflicted by similar prevalence rates as the forces of law and order, which is an improbable outcome. Clearly evidence of HIV as a state-centric threat is patchy and incomplete. By contrast, if we understand security to mean human and social development the picture is more complex. HIV poses a human-centric threat that bears further examination.

The global spread of HIV is shaped by local political, economic, cultural and societal attributes, and while concerns about the possible growth of HIV in PNG are legitimate there is also no inevitability about it reaching the adult prevalence of around 26-28 percent found in, say, Swaziland or Botswana (UNAIDS 2009, 27-28). Some parallels can be drawn with the political weaknesses of a number of African states, in that the many peoples within PNG have arguably never been cohesively united by a national identity - clan and wantok groups prevail and are only united in so far as they all attempt to use the PNG state to further the interests of their group (see Luker and Dinnen this volume, chapter one). Coincidentally, however, it is this diversity that also limits the threat of state collapse through coup or rebellion because 'ethno-linguistic fragmentation'

2 There are many reasons to question the accuracy of prevalence figures, both PNG-wide, as alluded to above, and for the military (see Pantumari and Bamne, this volume). 
means that small groups lack the resources to threaten the state, regardless of its weaknesses (Reilly 2004, 484). Yet as Reilly and Phillpot, among others, have argued: 'ethnic fragmentation, while ensuring the continuity of formal democracy at the national level, has undermined the development of social capital at the local level and effectively created a massive collective action problem' (Reilly and Philpott 2002, 927).

The state in PNG can be viewed as a large patronage network that divides and distributes the resources of the state but within which the players do not comprise sufficiently large groups to independently challenge the state. It is this form of instability that much of the scholarship on state failure in Africa has highlighted. Reno and others identify internal security challenges as being at the root of the problem of state failure in African 'quasi-states'. That is, internal conflict destabilises the patronage networks that many African states rely upon to maintain domestic law and order but not formal 'external' sovereignty. Historically, attempts to develop new networks often led to an over-reliance on external groups. However, in the post-Cold War environment the superpowers are no longer interested in proxy wars and blocs of allies so new relationships need to be built, be they with governments, investors or aid organisations (Reno 1997).

The relationship between the state, patronage networks and external actors described above was also evident in the Solomon Islands but has not had the same impact in PNG (Fraenkel 2004b, 5). The African experience does not necessarily translate to the South Pacific. For instance, a key element in the loss of superpower support mentioned above is a drying up of external aid, which must be supplemented from other sources. The opposite has been the case in PNG where Australian aid and intervention has increased markedly (O'Keefe 2005). Furthermore, external aid has become more tightly focused on state capacity-building and governance, rather than over-reliance on foreign investment primarily aimed at relieving the debt burden.

\section{Human Security and HIV}

So far we have discussed the state-centric perspective of the security implications of HIV. While the virus may have devastating consequences, HIV does not fit into the orthodox security paradigm. However, if one's starting point is human security rather than state survival the emphasis will be quite different (Altman 2003; Brower and Chalk 2003; Reid this volume).

In the early 1990s the UN Development Programme undertook a major review of the nature of security. The UNDP acknowledged that 'security symbolize[s] protection from the threat of disease, hunger, unemployment, crime, social 
conflict, political repression and environmental hazards'. Human security was defined as 'safety from such chronic threats as hunger, disease and repression... [and]...protection from sudden and hurtful disruptions in the pattern of daily life.' Therefore, human security involves economic, food, health, environmental, personal, community and political security (UNDP 1994, 22-5).

Clearly the concept and application of human security is drastically different to state-centric perspectives. One of the benefits of taking this broader approach is that it more accurately reflects the day-to-day reality facing most people. As stated earlier, for most people HIV is a greater threat than those of an orthodox military nature.

Discussion of the impact of AIDS must focus on the untimely deaths and incapacitation caused by epidemic HIV. Laurie Garrett has noted that 'the HIV/ AIDS pandemic is having severe demographic effects on hard hit societies, producing a so-called youth bulge, and reversing gains previously made in life expectancies and infant and child mortality rates' (Garrett 2005, 11). This situation points to a demographic imbalance that can only have long-term ramifications on state stability.

The long period between infection and death, often a period involving serious illness, is crucial to understanding the full impact of the epidemic on people and the states they live within. Well before a person living with HIV dies of HIVrelated disease, he or she often cannot work, and will require high-intensity care. The Brazilian example suggests that providing the best available treatments is actually a cost-effective measure for those states with sufficient means (Economist 2005, 69), though providing even the most basic level of medical care for people with HIV is very costly, especially in terms of human resources. In PNG, the burden of providing this care falls on the informal sector, and as prevalence rises, the existing shortage of skilled personnel in PNG will become more acute, just as the number of HIV patients requiring treatment increases.

Societies characterised by strong relationships of kin underpin traditionally weak states in Africa and the South Pacific, and PNG is a particularly good example. The loss of an able-bodied family member is a tragic circumstance with devastating interpersonal and familial consequences. In the absence of strong state services, death or disablement affects considerable numbers of dependents, families and communities. This contributes to the breakdown of the family and communities that form the fabric of society. Gender inequality in PNG is already stark (Eves this volume), and the impact of HIV is to increase the burden on women as both carers and providers of income. Of particular concern is the rising number of orphans who are growing up in increasingly fractured societies with little hope for the future. These children are likely to survive through marginal activity and not attend school (UNGA 2005; HEMIS 
2006, 56-57). Elderly people requiring care will also suffer as they are denied the benefits of the traditional social compact. When the cause of death and disablement reaches epidemic proportions it is no longer a matter of isolated family suffering - the fabric of society is strained and the resilience of the kin bonds that underpin the state in PNG will be tested.

As bread-winners require care or themselves become carers, household income drops, affecting the prospects of all members of the household. The poor get poorer because AIDS can exacerbate existing poverty and push low-income earners below the poverty line. In this manner AIDS is implicated in increased poverty and social inequality in Africa (UN 2001; UNAIDS 2008, 162). For instance, the burden of large numbers of burials is often mentioned as one of the real consequences of the epidemic at a household and community level. Many of those infected by the virus are, however, the ruling elites and middle classes who have received the largest per capita investment in human capital. These doctors, teachers, government officials are very difficult to replace. The institutional memory of the civil service can become incomplete (Pharoah 2003, 6). The loss of scarce human capital represents a loss of education, health, productivity, living standards and physical security (UNAIDS 2008, 174-177). Similar impacts have been modelled for PNG (CIE 2002; HEMIS 2006, 53-80).

Life expectancy in Sub-Saharan Africa is lower today than it was 30 years ago, with catastrophic drops in the most heavily AIDS-affected countries - falling, for example, by 16 years in Swaziland and 20 in Botswana (UNDP 2006, 265). This means that many people with a great deal of experience will die before they can pass their knowledge on and many others will become infected or die before they gain experience relevant to the effective functioning of families, communities and societies. The loss of the possessors of kinship knowledge can only alter and undermine the societal bonds that buttress the state in PNG. When HIV prevalence among younger people and amongst productive members of the workforce is high, population replacement and composition will also become an issue (Eberstadt 2002). A disproportionate number of infections occur amongst 15 to 49 year olds and due to 'equality of infection' it is commonplace for mothers to pass HIV on to their children (UN 2001, 31-32). Successes in reducing infant mortality in the 20th century have already been wiped out in some countries (WHO 2003, 7, 10-11). Similar projections have been made for PNG (CIE 2002; HEMIS 2006).

As AIDS exacerbates social fragmentation it becomes more and more difficult to mobilise the resources, human and material, to address the epidemic. Some African studies have posited a connection between AIDS and increased crime rates (Schonteich 2000, 57-66). Social dislocation caused by the potent mixture of the epidemic, conflict or state fragility increases 'survival' crime. Orphans may be forced onto the streets of large metropolitan areas where petty crime 
and commercial sex provide a means of survival (Fourie 2003). Furthermore, the usual response to crime is punishment but this can be counterproductive in the extreme as prisons are well known incubators for the disease (See Law this volume). In fact, in countries such as Russia and the US the single most effective means of HIV prevention may be to drastically reduce the prison population (Altman 2005). The link between AIDS and increased crime can only become stronger if the organs of law and order begin to fail.

\section{State Capacity and Security in PNG}

For states that function reasonably well to begin with, the HIV epidemic can degrade the capacity to provide basic services. However, these states usually have the capacity to marshal resources to head off any major threat. For states that have limited penetrative power within their societies and can be said to be already fragile, AIDS can limit the potential for capacity-building that can improve services. Law and order can break down and health and social welfare safety nets, already weak, can fail. The loss of human capital and economic growth has the potential to undermine the maintenance of various functions of government, especially highly technical areas (such as the medical services, economic management and taxation) or areas involved in maintaining law and order. Under these conditions the most basic medical treatments cannot be guaranteed, let alone treatment for HIV. Even the ability to provide basic technical services, such as sanitation and clean water, can be affected.

The preceding summary applies to many fragile states in Africa but is not readily transferable to PNG. As we have seen some government instrumentalities in PNG, such as the military and police, have not followed the African experience and been disproportionately degraded. They may be under-resourced and ineffective, AIDS is not the cause. Moreover, the PNG state has not reached much beyond the main population centres and many areas lack the most rudimentary services. In the presence of an expanding epidemic there can be little hope that this situation will improve-although it is unclear whether an improvement would occur in the absence of the epidemic.

Civil disorder and armed conflict, through such consequences as displacement, unregulated population flows and scarcity of essential foodstuffs, are likely to raise the incidence of HIV infection in some circumstances (Hankins et al. 2002). The lawlessness in PNG provides the potential for similar conditions to develop in certain locations. In many countries, injecting drug use (IDU), sexual violence and commercial sex, all of which exacerbate the spread of HIV, are becoming more widespread, even as the capacity for HIV prevention declines. In PNG, IDU is not an issue but the other factors are present. 
While a state's inability to provide physical security for its citizens is the most visible form of human insecurity, there are other implications, especially for the provision of essential services in health and education that are taken for granted in wealthier sates. As large employers in many countries, the government is most likely to introduce HIV testing of employees (as is definitely the case for the military). If they are lucky, those who are deemed unfit will receive health benefits. This adds a further burden to governments and society, one that appears unsustainable in many African countries (Quattek 2000).

Although estimates of the overall impact of the epidemic on the economy often vary widely, ${ }^{3}$ there is no doubt that AIDS has an impact on economic growth and inequality in fragile states. Premature death and disablement on epidemic levels also cause a major reordering in community and family support mechanisms, which in turn can lower agricultural productivity (du Guerny 2002). It is estimated that the agricultural workforce in the most affected African states has declined by between 3 and 13 percent due to AIDS. The resultant impact on food security could not be worse for societies where nutrition and clean water are problems and few reserves are in place to allow for the ever-present threat of famine (Fourie 2003).

As the Commission on AIDS in the Pacific (CAP) has noted, little research has been undertaken to date on the economic impacts of HIV in the Pacific or more specifically in PNG (CAP 2009, 46). Those studies that are available (e.g. CIE 2002, HEMIS 2006) are based on modeling, rather than measuring effects that have occurred. CAP however found that both public and private sector superannuation schemes in PNG reported an increase in claims due apparently in part to morbidity and mortality from AIDS (CAP 2009, 46). Also, a quarter of companies surveyed in 2009 reported that their operations in PNG had been negatively impacted by HIV over the previous five years, while threequarters anticipated negative impact in the coming five years (CAP 2009, 4950). Because only a minority of adults can find work in the formal sector, the sickness and death of a wage-earner affects the large number of dependents that employee usually supports. Effects of HIV and AIDS on the informal and subsistence sectors, which support the vast majority of the population, are even harder to track, but geographers expect that AIDS may affect food security, with communities in the most marginal and least endowed environments being most vulnerable (Hanson et al. 2001, 13).

3 Many studies focus on individual states and while illuminating about that state they do not provide a useful comparison with other states within the region or outside. See for instance Quattek 2000 and Shell 2000. 


\section{Conclusion}

The orthodox focus on military security that dominates International Relations limits our ability to analyse the implications of 'new' security threats, such as HIV and AIDS, for fragile states, such as PNG. This in turn creates a structural weakness in external responses to 'new' security threats in fragile states. As Dinnen and others argue, a state-centric view of security leads to the 'securitisation of aid, whereby the priorities of donor assistance are increasingly shaped by an external, and questionable, security agenda, rather than by domestic priorities' (Dinnen 2004, 5; italics in original). From this perspective serious domestic sources of instability are sidetracked by the donor's agenda focused on the external threats to sovereignty (Dinnen 2004, 14).

The epidemic poses a serious human security threat to Papua New Guineans. The combined effects of a growing epidemic have the potential to further weaken the state's capacity to provide basic services and public goods - from the maintenance of law and order to the provision of education and health services. As a consequence HIV transmission is likely to increase, and HIV programs will be further weakened.

Papua New Guinea is a weak state built upon societies that rely heavily on the strengths of kin and local community. It faces many challenges emanating from the combined effects of decolonisation and globalisation. Issues such as endemic crime and corruption have further reduced the capacity of the state to protect and promote the interests of its citizens. Some observers believe that PNG is teetering on the brink of collapse - that living conditions are degrading and that indigenous efforts to halt this malaise are not working. Even in the absence of the HIV epidemic Papua New Guineans would face a challenging future. Nevertheless, national institutions have proved to be surprisingly resilient. However, it is the ability of HIV and AIDS to weaken those strengths of society upon which the state rests that will make the epidemic so destructive in PNG.

\section{References}

Altman, Dennis. 2003. HIV and Security. International Relations 17 (4): 417-427.

Altman, Dennis. 2005. Rights Matter: Structural Interventions and Vulnerable Communities. Health and Human Rights 8 (2): 1-11.

Australia, Commonwealth Government of. 2005. Australia's National Security: A Defence Update 2003. Canberra: Commonwealth Government of Australia. 
Barnett, Tony and Gwyn Prins. 2005. HIV/AIDS and security: fact, fiction and evidence. A report to UNAIDS. London: London School of Economics. http:// www.lse.ac.uk (accessed 27 April 2010).

Barnett, Tony, and Alan Whiteside. 2002. AIDS in the Twenty First Century. Houndmills, Basingstoke: Palgrave Macmillan.

Brower, Jennifer, and Peter Chalk. 2003. Global Threat of New and Reemerging Infectious Diseases: Reconciling U.S. National Security and Public Health Policy. Washington D.C.: Rand.

Chappell, David. 2005. 'Africanization' in the Pacific: Blaming Others for Disorder in the Periphery? Comparative Studies in Society and History 47 (2): 286-316.

CIA (Central Intelligence Agency). The Global Infectious Disease Threat and its Implications for the United States. Washington DC.

CIE (Centre for International Economics). 2002. Potential economic impacts of an HIV/AIDS epidemic in Papua New Guinea. Report prepared for AusAID. http://www.ausaid.gov.au/ (accessed 27 April 2010).

CAP (Commission on AIDS in the Pacific). 2009. Turning the Tide: An OPEN Strategy for a Response to AIDS in the Pacific. Suva: Commission on AIDS in the Pacific.

De Waal, Alex. 2005. HIV/AIDS and the Threat of Social Involution in Africa. In Towards a New Map of Africa, ed. Ben Wisner, Camilla Toulmin and Rutendo Chitiga, 113-122. London: Earthscan.

Dinnen, Sinclair. 2004. Australia's 'New Interventionism' in the Southwest Pacific. In Governance Challenges of PNG and the Pacific Islands, ed. Nancy Sullivan, 59-71. Foreign Policy, Governance and Development: Challenges for Papua New Guinea and Pacific Islands. Madang, PNG: Divine University Press, and Caberra: State, Society and Governance in Melanesia Project, Australian National Univeristy.

Du Guerny, Jacques. 2002. Agriculture and HIV/AIDS. Bangkok: UNDP South East Asia HIV and Development Program.

Eberstadt, Nicholas. 2002. The Future of AIDS. Foreign Affairs 81 (6): 22-45.

Economist. 2005. Roll out, roll out. The Economist, 30 July 2005:69.

Elbe, Stefan. 2003. Strategic Implications of HIV/AIDS. Oxford: International Institute for Strategic Studies/Oxford University Press. 
FAO. 2001. The Impact of HIV/AIDS on Food Security. UN Food and Agriculture Organization, Committee on World Food Security, Twenty-seventh Session, Rome, 28 May-1 June 2001. http://www.fao.org/docrep/meeting/003/ Y0310E.htm (accessed 27 April 2010).

Fourie, Pieter and Martin Schonteich. 2001. Africa's New Security Threat: HIV/ AIDS and Human Security in Southern Africa. African Security Review, 10 (4). http://www.iss.co.za/pubs/asr/10no4/fourie.html (accessed 27 April 2010).

Fourie, Pieter. 2003. Die, The Beloved Countries: Human Security and HIV/AIDS in Africa. Pretoria: South African Regional Poverty Network. http://www. heart-intl.net/HEART/100507/DIE,TheBelovedCountries.pdf (accessed 27 April 2010).

Fraenkel, J. 2004a. The Coming Anarchy in Oceania? A Critique of the 'Africanisation' of the South Pacific Thesis. Commonwealth and Comparative Politics 42 (1): 1-34.

Fraenkel, J. 2004b. Political Instability, 'Failed States' and Regional Intervention in the Pacific. In Redefining the Pacific; Regionalism; Past; Present and Future, ed. Jenny Bryant-Tokalau and Ian Frazer. Dunedin: University of Otago.

Garrett, Laurie. 2005. HIV and National Security: Where are the Links? New York: Council on Foreign Relations.

Hammar, Lawrence. 2007. Homegrown in PNG - Rural Responses to HIV and AIDS. Oceania 77 (1): 72-94.

Hankins, C., S., Friedman, T., Zafar, and S. Strathdee. 2002. Transmission and Prevention of HIV and Sexually Transmitted Infections in War Settings: Implications for Current and Future Conflicts. AIDS 16 (17): 2245-2252.

Hanson, L. W., Allen, B. J., Bourke, R. M., and T. J. McCarthy. 2001. Papua New Guinea Rural Development Handbook. Canberra: The Australian National University.

HEMIS (HIV Epidemiological Modelling and Impact Study). 2006. Impacts of HIV/AIDS 2005-2025 in Papua New Guinea, Indonesia and East Timor. Canberra: AusAID.

Kendino, Gideon. 2005a. Current Developments in the Management of HIV/AIDS in the PNG Defence Force, 15th Asia-Pacific Military Medicine Conference (APMMC XV) in Hanoi, Vietnam May 8-13, 2005.

Kendino, Gideon. 2005b. PNG: 38 Soldiers Die Of AIDS in PNG. Pacific Magazine, 25 February 2005. 
May, R. 2004. A Brief Overview of Pacific Security Issues. Foreign Policy, Governance and Development: Challenges for Papua New Guinea and Pacific Islands. Madang, PNG: State Society and Government in Melanesia.

O'Keefe, Michael. 2005. Australian Intervention in Its Neighbourhood: Sheriff and Humanitarian? In Righteous Violence: The Ethics and Politics of Military Intervention, ed. Tony Coady and Michael O'Keefe, 75-98. Melbourne: Melbourne University Publishing.

O'Keefe, Michael. 2008. State Fragility and AIDS in the South Pacific. In AIDS. The Hague: Security and Conflict Initiative, Netherlands Institute of International Relations Clingendael. http://asci.researchhub.ssrc.org/statefragility-and-aids-in-the-south-pacific/attachment (accessed 27 April 2010).

PNG National AIDS Council Secretariat and partners. 2008. UNGASS Country Progress Report. Reporting Period: January 2006-December 2007 Port Moresby: PNG National AIDS Council Secretariat.

Pharaoh, Robyn and Martin Schonteich. 2003. AIDS, Security and Governance in Southern Africa: Exploring the Impact. Institute for Security Studies, Paper no. 65. Johannesburg: Institute for Security Studies.

Quattek, Kristina. 2000. The Economic Impact of AIDS in South Africa: A Dark Cloud on the Horizon. Occasional Paper. Johannesburg: Konrad Adenauer Foundation South Africa.

Reilly, Ben and Robert Phillpot. 2002. 'Making Democracy Work' in Papua New Guinea. Asian Survey 42 (6): 906-927.

Reilly, Ben. 2000. The Africanisation of the South Pacific. Australian Journal of International Affairs 54 (3): 261-268.

Reilly, Ben. 2004. State Functioning and State Failure in the South Pacific. Australian Journal of International Affairs 58 (4): 479-493.

Reno, William. 1997. African Weak States and Commercial Alliances. African Affairs 96: 165-185.

Schonteich, Martin. 2000. Age and AIDS: A Lethal Mix for South Africa's Crime Rate. Occasional Paper. Johannesburg, Konrad Adenauer Foundation South Africa: 57-66.

Shell, Robert. 2000. Halfway to the Holocaust: The Economic, Demographic and Social Implications of the AIDS Pandemic to the Year 2010 in the Southern African Region. Occasional Paper. Johannesburg: Konrad Adenauer Foundation South Africa. 
Tow, William, Ramesh Thakur and In-Taek Hyun eds. 2000. Asia's Emerging Regional Order: Reconciling Traditional and Human Security. Tokyo: United Nations University Press.

UNAIDS. 2008. Report on the Global AIDS Epidemic. Geneva: UNAIDS. www. unaids.org

UNAIDS. 2009. AIDS Epidemic Update. December 2009. Geneva: UNAIDS. www. unaids.org

UN. 2001. Global Crisis - Global Action Fact Sheet. New York: United Nations.

UNDP. 1994. World Development Report. Geneva: UNDP.

UNDP. 1999. World Development Report. Geneva: UNDP.

UNDP 2006. Human Development Report 2006: beyond scarcity. New York: UNDP

UNGA (United Nations General Assembly). 2005. High Level Meeting on HIV/ AIDS, Discussion Paper for the Round Table on Orphans and Children Made Vulnerable by HIV/AIDS. New York: United Nations.

Whiteside, Alan, Alex de Waal and Tsadkan Gebre-Tensae. 2006. AIDS, Security and the Military in Africa: A Sober Appraisal, African Affairs 105 (409): 201-218.

WHO. 2003. Annual Report 2003. Geneva: World Health Organisation. 